Article

\title{
The Nordic Balance Revisited: Differentiation and the Foreign Policy Repertoires of the Nordic States
}

\author{
Kristin Haugevik* and Ole Jacob Sending \\ NUPI-Norwegian Institute of International Affairs, 0130 Oslo, Norway; E-Mails: kmh@nupi.no (K.H.), ojs@nupi.no (O.J.S.) \\ * Corresponding author
}

Submitted: 16 June 2020 | Accepted: 24 August 2020 | Published: 3 November 2020

\begin{abstract}
Nordic governments frequently broadcast their ambition to do more together on the international stage. The five Nordic states (Denmark, Finland, Iceland, Sweden and Norway) also share many basic goals as foreign policy actors, including a steadfast and vocal commitment to safeguarding the 'rules-based international order.' Why then, do we not see more organized Nordic foreign policy collaboration, for example in the form of a joint 'grand strategy' on core foreign policy issues, or in relation to great powers and international organizations? In this article, we draw on Charles Tilly's concept of 'repertoires' to address the discrepancy between ambitions and developments in Nordic foreign policy cooperation, highlighting how the bundles of policy instruments-repertoires-that each Nordic state has developed over time take on an identity-defining quality. We argue that the Nordic states have invested in and become attached to their foreign policy differences, niches, and 'brands.' On the international scene, and especially when interacting with significant other states, they tend not only to stick to what they know how to do and are accustomed to doing but also to promote their national rather than their Nordic profile. While Nordic cooperation forms part of all the five states' foreign policy repertoire in specific policy areas, these are marginal compared to the distinctive repertoires on which each Nordic state rely in relation to more powerful states. It is therefore unlikely that we will see a 'common order' among the Nordic states in the foreign policy domain in the near future.
\end{abstract}

\section{Keywords}

cooperation; foreign policy; identity; Nordic region; repertoires

Issue

This article is part of the issue "Rediscovering Nordic Cooperation" edited by Anne Elizabeth Stie (University of Agder, Norway) and Jarle Trondal (University of Agder, Norway/ARENA University of Oslo, Norway).

(C) 2020 by the authors; licensee Cogitatio (Lisbon, Portugal). This article is licensed under a Creative Commons Attribution 4.0 International License (CC BY).

\section{Introduction}

Nordic government representatives frequently broadcast their ambition to do more together on the international stage. Proposals range from a former Norwegian foreign minister's call for the Nordics to apply for a joint seat at the G20 (Støre, 2009), and the Finnish President's hyperbolic declaration that "the Nordics are a superpower" during a joint-Nordic summit with US President Barack Obama (Niinistö, 2016). In 2017, the Nordic Council published its first international strategy, urging the Nordic governments "to exploit the opportu- nities inherent in Nordic co-operation to a far greater extent" (Nordic Council, 2017). The oft-stated rationale for increased Nordic foreign policy collaboration is that the five Nordic states share many basic traits and foreign policy objectives, including an explicit and steadfast commitment to upholding the 'rules-based international order' and its accompanying institutions and belief-systems. Seeking responses to new international challenges, the Nordic governments have been conscious that there may be unexploited potential in pooling their resources. The Nordic populations are also supportive: More than 90 percent deem Nordic cooperation 'important' or 'very 
important,' and around two-thirds would like to see increased cooperation (Andreasson \& Stende, 2017). This presents us with a puzzle: Despite government ambitions and widespread public support, Nordic foreign policy cooperation in the international domain remains modest. There are few indications that a formalized, discernable, or overarching 'Nordic foreign policy' is in the making. Given the five Nordic states' shared assessments of the international environment, their similar values, overlapping interests, good internal relations, and oftrepeated aspiration to collaborate more, both interestand identity-driven theories of action would anticipate intensified cooperation. In short: If the Nordic states are so similar, and the incentives to collaborate so strong, then why does the 'Nordic dimension' not feature more prominently in the everyday foreign policies of the individual Nordic states?

Answering this question has a bearing on our understanding of the push and pull factors of Nordic cooperation, and thus also on whether the Nordics can be said to represent an "integrated and independent 'common order"' as laid out by the Academic Editors in the editorial to this thematic issue (Stie \& Trondal, 2020). We argue that foreign policy is a domain where shared societal and political traits do not make Nordic joint positions and action more likely. Instead, each Nordic state seeks individual recognition and assistance from significant others, also when a collective Nordic approach may have given them a stronger voice and platform. We suggest that this is because the structural conditions of the Nordic states: Being small-to-medium powers dependent on positioning themselves in relation to more influential players, they have developed niche strategies to signal their own distinctiveness, also vis-à-vis one another. In doing so, they rely on policy instruments which have emerged over time, spawned by decisions made in the wake of the Cold War. We draw on Charles Tilly's concept of 'repertoires' (Tilly, 1979) to highlight how these bundles of policy instruments take on an identity-defining quality. We propose that the Nordic states are more invested in their foreign policy differences than they tend to acknowledge in joint statements and documents and that their attachment to these differences hinders more substantial Nordic integration in the foreign policy domain. While often advocating the Nordic brand when they meet on the international arena, in day-to-day foreign policy, the Nordic states are also competing for attention, visibility, and influence. Given the relative socioeconomic and political homogeneity of the Nordics, there is, therefore, a premium on positioning themselves in relation to one another when pursuing attention and support from more powerful states. Seeking access to policymakers in Washington, DC, Denmark has foregrounded its 'super-Atlanticism,' and Norway its proficiency in peace and reconciliation, for example. In the quest for attention, there is not an insignificant element of the 'narcissism of small differences' involved, in that each state 'doubles down' on its distinctiveness. It follows from this that we do not see identity as 'coming before' or explaining action. Rather, identity has to be enacted and performed (Butler, 1997; Epstein, Lindemann, \& Sending, 2018), and such performances are done through available repertoires. By investing in distinct foreign policy identities and strategies, each Nordic state has tailored its own repertoire, which creates path dependencies and around which its foreign policy is organized.

We begin with a brief review of theory-driven scholarship on Nordic foreign policy cooperation before we present the concept of foreign policy repertoires in more detail and explain why it provides leverage for understanding Nordic foreign policies and the (lack of) formalised, strategic coordination and collaboration. Next, we compare and discuss the Nordic states' individual foreign policy choices, especially in relation to key international actors, noting that the Nordic component of each state's foreign policy remains modest. While some areas of intra-Nordic foreign policy cooperation, for example, regional defence, have moved in the direction of more formalised cooperation and 'deeper' integration, other areas, such as the Nordics' overarching approaches to the EU, continue to be marked by 'differentiation.' Finally, when it comes to relations with the US, Russia, and China, and on joint responses to global challenges, we find that despite bold ambitions, these remain characterised by separate political goals and actions ('disintegration'). We conclude that due to the robustness of distinct national foreign policy repertoires, overarching Nordic foreign policy coordination is likely to remain ad hoc and case-by-case oriented in the foreseeable future.

\section{The Literature on Nordic Foreign Policy Cooperation}

Scholarly work on the Nordic region and on 'Nordicness' ranges across multiple subdisciplines. As discussed elsewhere in this special issue, we see different degrees and mechanisms of cooperation within the Nordic region across a range of issue areas. Over the last few years, there has been renewed political interest in how the Nordics could pool their (material and social) resources together on the international arena, both for national and regional gain as well as for the greater good of international politics writ large. This 'revival' or 'renaissance' of the Nordic dimension is echoed in the scholarly literature and is manifest in the quantity of recent edited volumes and special issues on Nordic cooperation. One bulk of this research highlights the Nordic region as being particularly successful in managing globalization, with the Nordics typically featuring among the top-ten in the UN's Human Development Index, and having a reputation and track record as 'norm entrepreneurs' (Ingebritsen, 2002) and international 'do-gooders' (Rumelili \& Towns, in press). As one observer has pinpointed, during the Cold War, "the Nordic bastion was gradually reinterpreted to mean not only relatively similar societal identities, but also the idea that these identities represented progress: 'better off,' not just 'different from"' (Mouritzen, 1995, 
p. 10). Much recent scholarship also discusses (and thus helps keep alive) this idea: That a specific 'Nordic brand' exists on the international arena, that the Nordics are models or frontrunners "with best practices to share" (Strang, 2016, p. 1), and that a new kind of 'Nordism' or 'Nordicness' may now be on the rise (Hyde-Price, 2018).

A second strand of research has focused on how the Nordic states-individually and (potentially) as a collective-relate to great power politics and individual great powers. Recent studies have compared Nordic approaches to China (Forsby, 2019; Sverdrup-Thygeson, Lindgren, \& Lanteigne, 2017) and Russia (Hansen, 2018; Kragh, 2018; Rowe, 2018; Smith, 2018), as well as responses to changes in British foreign policy following the Brexit referendum (Fägersten et al., 2018), and US foreign policy under the Trump administration (Breitenbauch, 2017). Many of these studies highlight how foreign and security policy choices in the Nordic states are heavily conditioned by structural factors, where realpolitikal considerations kick in. The extraNordic conditioning of foreign and security policy was also present in scholarly literature in the early Cold War years, with, for example, Arne Olav Brundtland's work on 'the Nordic balance' (1966). Brundtland argued that the alliance choices of the Nordic states-Swedish neutrality, Finland's Friendship, Cooperation and Assistance Treaty with the Soviet Union, and Danish and Norwegian NATO membership-balanced one another and helped diminish great power tensions in the region as a whole. These choices were perhaps less the result of a "deliberate design" than they were an "aggregated result of incremental decisions and adjustment" (Holst, 1990, p. 8), but they served to situate each Nordic state in an institutional setting that balanced between competing concerns. However, the parameters for this internal Nordic balance changed with the end of the Cold War and with Finland and Sweden joining NATO's Partnershipfor-Peace programme and becoming members of the EU. In 1992, Ole Wæver diagnosed that "there will still be lots of Nordic networks, lots of cooperation built on the closeness of the languages, and so on. But politically and emotionally speaking, the driving idea will not be Nordism" (Wæver, 1992, p. 100). Wæver deemed it unlikely that 'Norden' could come to represent an alternative organization to the European community, or that the Nordic states in the future would form a functional subgroup within the EU institutions and structures. Instead, he anticipated "a Baltic (possibly also Arctic) rearticulation of Norden" (Wæver, 1992, p. 96).

In the prolongation of such analyses, a number of in-depth comparative studies have emerged over the last three decades, mapping and comparing how the Nordic states have related to key regional and international organizations of which some or all are members. The literature on Nordic approaches to European integration is particularly rich, including in the subfield of foreign, security, and defence policy (e.g., Bailes, Herolf, \& Sundelius, 2006; Iso-Markku, Innola, \& Tiilikainen,
2018; Rieker, 2006). Seeking to explain differences in the Nordic states' approaches to European integration more broadly, one influential study identified "different visions of European unity" as particularly important (Ingebritsen, 1998, p. 184). The argument was that the governments of Denmark, Iceland, and Norway had adopted a 'British-style' intergovernmentalist vision of Europe, whereas the governments of Finland and Sweden had gone along with a 'German-style' multilateralist vision. The former position combined a strong preference for national autonomy with Atlanticist security solutions; the latter foregrounded supranational ambitions and a stronger European security dimension (Ingebritsen, 1998, pp. 184-185). A few years later, an alternative account was offered by a group of scholars associated with the 'Copenhagen School.' Setting out to explain how each Nordic state had ended up with their current approach to the EU, the scholars traced the formation of national identity historically, showing how the individual states' self-understandings had emerged in relation to specific, dominant representations of Europe (Hansen \& Wæver, 2002). Studies have also examined the dynamics of Nordic collaborative efforts within multilateral bodies such as the UN, including variations in their individual approaches which could be ascribed to differences in their foreign policy identities and profiles (Jakobsen, 2017; Laatikainen, 2003). In what follows, we build on these insights and add to them by stressing how foreign policy identities become attached to and performed through distinct foreign policy repertoires. Thus, starting with the imperative of securing territorial integrity given certain structural conditions, we highlight how foreign and security policy choices become 'sticky' and generate path dependencies because of the repertoires around which identities come to be organized. The Nordic states have often taken pride in being reliable, responsible and recognizable as foreign policy actors. This can help explain why-despite a range of shared political and socioeconomic characteristics and stated ambitions of further Nordic integration - the Nordic states foreign policies have remained distinct.

\section{Layered Foreign Policy Repertoires}

Much of the scholarly work on foreign policy has sought to explain state action either by mapping the prevailing material interests at stake, identifying key norms to which the state is committed, or considering foreign policy as a product of the international structural parameters within which the state operates. In one authoritative understanding, foreign policy actions "are linked together in the form of intentions, cognitive-psychological factors, and the various structural phenomena characterizing societies and their environments" (Carlsnaes, 2013, p. 317). Other approaches have stressed how identity and culture, either in the form of practice and habit (Hopf, 2010; Pouliot, 2008) or institutionalized norms (Checkel, 2005; Finnemore, 1996), are key to understand- 
ing how foreign policy is formulated and put into action. Much of the foreign policy literature thus foregrounds what we may call endogenous drivers of states' foreign policy choices, but notes at the same time how states operate within a specific structural context and under specific power-political circumstances. Such assessments recur also in the literature on the Nordic states' foreign and security policies. While we have no quarrel here with analyses that foreground the primacy of national interests defined in terms of state survival and economic interests, nor analyses that highlight changes in states' interests due to international and regional norms, we draw attention to how an emphasis on available material and social means-repertoires-allow us to offer a different account of foreign policy in the Nordic region. Independently of the identity and intentions of any given state, the (perceived) availability of policy instruments is a necessary ingredient of foreign policy action. Foreign policy choices are heavily conditioned by what, for material, historical, political, and social reasons, are considered to be possible policy interests and action paths. That is: States tend to formulate and conduct their foreign and security policies based on what they see as available paths and instruments-investing in an alliance, providing development aid, contributing military troops, supporting multilateral institutions and so on-and only change these gradually. In doing so, they develop and become accustomed to, specific ways of doing things, which become institutionalized in how they signal to and interact with key international players. Extending Charles Tilly's concept of repertoires (1979), Goddard, MacDonald, and Nexon (2019) have suggested that statecraft and foreign policy can be fruitfully analysed as revolving around such repertoires: "States enjoy, in theory, an infinite or at least a very broad range of tools....They may, for example, mobilize their military forces, conquer their neighbors, muster alliances, impose sanctions, 'name and shame,' or petition international bodies" (p. 312).

Thus understood, a repertoire is the configuration of a set of tools or instruments that are typically drawn upon to advance different interests in interaction with others. Repertoires are not static but evolve slowly, as new elements are added. In Tilly's phrasing: "Repertoires vary from place to place, time to time" but innovation and change take place "within the limits set by the repertoire already established for their place...[and]...time" (Tilly, 2006, p. 35, emphasis added). We contend that repertoires are also relatively resistant to systemic changes. There are two key reasons for this. The first is that path-dependency is created when actors invest in particular ways of doing things, becoming good at and developing networks around certain issue-areas (e.g., 'digitalization,' 'women, peace and security' or 'peace and reconciliation') or certain instruments (e.g., sanctions or multilateral investments; Peters, Pierre, \& King, 2005). The second reason is that states attach their identity to and perform their distinctive profile through these repertoires. Repertoires are therefore central for states' ability to signal to other states who they are, what they are capable of doing, and what others can expect from them (Tilly, 2006, p. 41; see also Neumann \& Sending, 2020; Rowe, 2020, p. 4). By drawing attention to the repertoires that each state has developed over time, we highlight how what are considered as possible tools or action paths, come to structure the type of foreign policy that can be conducted. This is so because foreign policy identity or profile is not just 'there,' available for everyone to see or adopt. Rather, identity comes into being through actions and performances, which in turn necessarily rely on what Vincent Pouliot has referred to as 'available ways of doing things' (Pouliot, 2020). This stress on performance is important, as it implies, in Duvall and Chowdhury's (2011, p. 338) apt formulation, that "there is no doer before the deed." In other words: The kind of foreign policy actors that Denmark, Iceland, Finland, Norway or Sweden are, in the eyes of other international actors, emerges through that state's foreign policy actions, actions which are in turn conditioned by historically established repertoires. By dint of its historical decisions and investment of resources, Finland has a different foreign policy repertoire than Norway; this fact structures the Finnish and Norwegian governments' respective room for manoeuvre on the international arena and in relation to significant other actors.

Understanding foreign policy through a focus on repertoires becomes even more important when we consider the structural conditions under which the Nordics find themselves, having to manage conflicting demands in their environment. The literature on hegemony suggests that repertoires rest to a considerable degree on the provision of public or club goods, such as security guarantees, an open trade system, and so on (Cooley \& Nexon, 2020). It can be seen as a contract, where the hegemon provides security guarantees in exchange for political loyalty from the subordinate state (Lake, 2009). In this perspective, both Denmark and Norway have, bilaterally and through their NATO membership, entered into a contract with the US for security guarantees, offering political loyalty and support in exchange. But a quick glance at the foreign policies of Denmark and Norway also reveals how much both states' foreign policies are organized around seeking attention from and access to US policymakers. Both states want to be recognized as reliable, competent, and useful partners, and they, therefore, strive to contribute to the production of the club and public goods that the US-qua hegemonis assumed to produce for them. Denmark and Norway's contributions to the wars in Afghanistan and Libya are cases in point. At the same time, these two states' foreign policy repertoires are not, as realist accounts might claim, solely organized around the pursuit of military support, or security: understood as territorial survival. Ontological security-to preserve and be recognised as a particular kind of self-will, in many cases be as or even more important (Mitzen, 2006), particularly for smaller states like 
the Nordics. The quest for political and diplomatic clout and recognition from key others will be important objectives in and of themselves (Jakobsen, Ringsmose, \& Saxi, 2018; Lindemann \& Ringmar, 2015). A focus on repertoires adds complexity to accounts focusing on identity as a foreign policy driver, because it takes into account how states also use their identities strategically, to acquire access, influence, and support. Being a frontrunner in development assistance or peace and reconciliation, for example, can be a comparative advantage, and something a smaller state can use as a bargaining chip in efforts to gain attention from a significant other state. This explains why small states in some settings will emphasize rather than tone down their uniqueness in a group of likeminded peers, engaging in a "friendly kind of status competition" (Røren, 2019). In the Nordic context, Denmark stands out as the most 'Atlanticist,' Sweden the most 'feminist,' and so on.

\subsection{The Individual Foreign Policy Repertoires of the Nordic States}

There are many similarities in the five Nordic states' foreign policies, including in their geopolitical framework conditions, their resources, their political systems, and in how they see themselves and their room for maneuver in the international system. All the Nordic states have been staunch and vocal supporters of democratic values, the rule of law, and good governance, as well as of multilateral frameworks that have guaranteed the upholding of these since the late 1940s: the UN, NATO and the $\mathrm{EEC} / \mathrm{EU}$. At the same time, important differences in the individual states' foreign policy identities and repertoires remain-differences which can in large part be traced back to paths taken and decisions made during and in the wake of the Cold War.

In the early Cold War years, Denmark, Iceland and Norway chose to seek security guarantees from the Atlantic powers, bilaterally and through NATO. From 1951, Iceland also had US military forces stationed at the Keflavík military base. By contrast, Sweden opted for a policy of neutrality in wartime and freedom from alliances in peacetime, while Finland, also adopting a policy of neutrality, signed an agreement of friendship, cooperation, and mutual assistance with the Soviet Union. In one influential reading, these differences in chosen paths constituted a 'Nordic balance,' where the Nordic states' individual security choices complemented and balanced one another in relation to the great powers and helped secure stability in the region as a whole (Brundtland, 1966). While the collapse of the Soviet Union and subsequent end of the Cold War made these intra-Nordic differences less profound and critical, past choices and experiences continue to shape what these states consider to be feasible foreign policy choices and instruments. All the Nordic states have adapted their foreign policies since the Cold War came to an end, as evident for example in their approaches to NATO and the EU. However, they have made these adjustments in a way that is consistent with their historically established foreign policy repertoires, which were defined by their respective positioning vis-à-vis the two key security actors during that period: the US and Russia. 70 years after NATO's foundation, and despite the US having become a more unpredictable foreign policy actor under the Trump Administration, Denmark and Norway continue to put Atlanticism first. Both governments insist that bilateral security ties with the hegemon remain as strong as ever. In Iceland's case, the US withdrawal from the Keflavík base in 2006 and its lack of support to Iceland during the financial crisis in 2008, triggered a domestic debate about whether Iceland needed to seek military and economic shelter elsewhere (Thorhallsson, 2018). Still, Atlanticism has remained a key pillar in Icelandic security and defence policy, and the Icelandic EU membership application-submitted in 2009-has since been put on ice. In view of this, Finland and Sweden's repositioning towards closer cooperation with the US, in recent years, including through bi- and trilateral statements of intent, could at one level be seen to represent a convergence around a Nordic 'norm' to cooperate closely with the Atlantic hegemon. The joint statement by the Nordic defence ministers in 2015, describing Russia's recent actions as "the greatest challenge to the European security situation," could be interpreted in the same fashion (Søreide, Wammen, Haglund, Sveinsson, \& Hultqvist, 2015). Both Finland and Sweden have also entered into partnership agreements with NATO, allowing them to take part in working procedures and exercises (e.g., Trident Juncture) alongside member states. Still, while Sweden is taking a step towards the US and NATO, it is holding on to its traditional repertoire of freedom from alliances (Fägersten \& Jerdén, 2018). Similarly, despite seeking Atlanticist defence guarantees, Finland has been careful to signal that good neighbourly relations and dialogue with Russia remain a priority (Creutz, 2018). Hence, while the intra-Nordic differences in approach to and relations with the US hegemon may seem smaller and less divisive today than they were during the Cold War, they remain significant enough to preclude a unified Nordic approach. Approaching the US under a Nordic umbrella could blur important differences between the states, and hence make it more difficult for each state to communicate its special position and needs to Washington, DC.

A similar picture emerges in relation to the EU. In the early Cold War years, the Nordic states reached similar conclusions and remained outside of the early initiatives for Western European economic integration. Together with Britain, the three Scandinavian states instead formed the European Free Trade Association, hence choosing to be part of 'the-outer-seven' rather than the 'inner-six' constellation in Europe. However, when Britain u-turned and applied for membership after all, both Denmark and Norway followed. In 1973, Denmark broke ranks with the rest of the Nordics and entered the EEC while Norway remained outside after 
a majority of voters rejected membership in a nationwide referendum. In 1995, a Norden-in-Europe dimension seemed more possible when Sweden and Finland also joined the EU. However, while both Norway and Iceland are members of the European Economic Area and have also 'opted in' to a wide range of EU policies beyond that agreement, they remain outside of the main EU decision-making bodies. Accordingly, they have to exercise diplomacy 'through the back door' to ensure influence and access (Haugevik, 2017). For the Nordic EU insiders (Denmark, Finland, and Sweden) the EU has become a key arena for inter-state diplomacy and foreign policy formulation. At the same time, and while these three often share basic views, they have maintained distinct foreign policy profiles. Despite being the first Nordic EEC member state, Denmark has upheld a reputation as the more skeptical 'footdragger' in the context of European integration-as the Danish opt-outs under the justice, security, and defence policies suggest (Adler-Nissen, 2014; Andersen, 2018). At the other end of the scale, Finland is the only Nordic state to have adopted the Euro, making it the most 'Europeanised' of the Nordic member states in terms of vertical integration. Thus, under the broader EU- European Economic Area umbrella, we continue to see distinct foreign policies of each Nordic state (Leruth, Gänzle, \& Trondal, 2018). Nordic cooperation within the EU has so far taken place either on an informal, ad hoc basis or in a broader format which also includes the three Baltic states (Iso-Markku et al., 2018, pp. 9-16).

In recent years, China has also risen up the foreign policy agenda of all five Nordic states. Having seen trade relations with China increase, all have sought to balance initiatives to boost economic ties, with the voicing of concern regarding human rights. The last decade, both Norway and Sweden have experienced profound difficulties in their bilateral relationship with China following what the Chinese government has deemed violations of the principle of non-interference: The Norwegian Nobel Peace Prize to the dissident Liu Xiaobo in 2010 and the Swedish PEN's award to dissident Gui Minhai in 2019. While a joint Nordic strategy towards China on the issue of human rights may seem like a logical ambition, the Nordic states have so far assumed tailored, national approaches. As Andreas Bøje Forsby (2019, p. 13) has summarized, Sweden "tends to be the most active" in publicly criticizing Chinese human rights violations, while Denmark and Norway have been "somewhat more discreet in their moral activism." Finland and Iceland have both adopted "a relatively pragmatic position vis-à-vis Beijing" (Forsby, 2019, p. 13). For all the Nordics, Forsby observes, the general tendency has been to handle human rights issues in "closed-doors bilateral meetings" or, in Denmark, Finland and Sweden's case, "'outsource' them to Brussels as part of the recurring EU-wide human rights dialogue" (Forsby, 2019, pp. 13-14). Therefore, in relations with China, the Nordic states overall remain an 'uncoordinated quintet' (Sverdrup-Thygeson \&
Hellström, 2016), thus serving as an illustration of how perceived needs to tailor and fine-tune approaches to national needs, may effectively hinder a collective Nordic approach. While there is a clear 'pull' to establish a more clearly articulated 'Nordic' component of foreign policy, the structural conditions of each state are such that signalling niche competencies and distinct 'assets' matter more.

\subsection{A Joint Nordic Foreign Policy Repertoire?}

The basis for intra-Nordic cooperation is the Helsinki Treaty (1962), most recently revised in 1995 . The interparliamentary Nordic Council was founded in 1952 and the intergovernmental Nordic Council of Ministers in 1971. Intra-Nordic coordination and collaboration from these agreements cover a broad range of issues, including infrastructure, telecoms, the environment, tourism and popular culture, and the free movement of labour. To varying degrees, these initiatives help underpin the idea that a common 'Nordic order' exists. 'Norden in Norden' has been the story about a (Scandinavian) language community, where communication is marked by informality and high levels of inter-state trust. This image of a closely-knit Nordic order and community has formed the basis for discussions both among the Baltic states and in the Balkans, where the Nordic region could serve as a reference point for successful integration.

In prolongation, the Nordic governments have at times sought to capitalize on the success of the 'Nordic model' as a response to globalization, as illustrated for example by the Nordic prime ministers' joint initiative 'Nordic Solutions to Global Challenges' in 2015. The Nordic Council of Ministers has also hinted at a bolder foreign policy ambition, despite this formally belonging outside of these institutional structures. In 2017, the Nordic Council presented its first international strategy (Nordic Council, 2017), which has been used to leverage face time with key allies. The Nordic heads of government's much-publicized joint meeting with Obama in Washington, DC in 2016, was followed up by a Nordic summit with India's prime minister in 2018, and a joint meeting with Angela Merkel in Reykjavik in 2019 to discuss climate change. China has also signalled interest to engage in the ' $5+1$ ' format (Iso-Markku et al., 2018, p. 14).

Seeking to operationalize the sometimes-lofty political ambitions for more comprehensive and committing Nordic foreign policy cooperation, in 2008, the five Nordic foreign ministers invited an expert group led by former Norwegian foreign minister Thorvald Stoltenberg, to "draw up proposals for closer foreign and security policy cooperation between the Nordic countries" (Stoltenberg, 2009). The final report presented 13 proposals for formalizing and strengthening Nordic cooperation in the foreign policy and security domain. The proposals varied in ambition, scope, and feasibility. Thematically, they covered peacebuilding, air surveil- 
lance, maritime monitoring and Arctic issues, societal security, cooperation between the foreign services, military cooperation, and a Nordic declaration of solidarity (Stoltenberg, 2009). With its concrete, and in some cases bold proposals, the report has become a standard reference in policy and scholarly debate into the possibilities for, and constraints of, Nordic foreign and security collaboration. It also stimulated debate about the Nordic governments' willingness and ability to translate ambitions into concrete initiatives and structures. One decade later, a review report commissioned by the Icelandic presidency of the Nordic Council of Ministers, found that three of the proposals from the Stoltenberg report had been implemented more or less in full: Nordic cooperation on surveillance of the Icelandic airspace, a Nordic resource network to protect against cyber-attack, and cooperation between the Nordic foreign services (Haugevik \& Sverdrup, 2019). All these could be seen as proposals that fitted well within and supplemented each state's existing foreign and security policy repertoires, and as instances where collaboration did not duplicate efforts already taking place within NATO or the EU. Further, the review found that some progress had been made on seven proposals, if not necessarily in the exact way and form envisioned by the Stoltenberg report. This included the establishment of a Nordic maritime monitoring system and a maritime response force; the strengthening of Nordic cooperation on Arctic issues; the establishment of a disaster response unit; the increase in intra-Nordic military cooperation on transport, medical services, education, materiel, and exercise ranges; the establishment of an amphibious unit; and the issuing of a Nordic declaration of solidarity. Finally, on three of the proposals-the issuing of a Nordic stabilization task force, a satellite system for surveillance and communications, and a war crimes investigation unit-the review found that little or nothing had happened (Haugevik \& Sverdrup, 2019). What these three proposals had in common was that they all involved the establishment of specific new structures and units and a high degree of institutionalisation.

These findings suggest that while it is important for the Nordic states to signal a willingness to cooperate, such ambitions are only translated into action to the degree that they fit with the state-specific repertoires around which foreign policy decisions are made. In general, Nordic cooperation within the Nordic region, or administratively in embassies around the world, may be easier to realize because they add to national repertoires, and do not duplicate functions already covered by existing structures or institutions such as NATO or the EU. However, also in these respects, there is a danger of underestimating intra-Nordic differences, for example, in bureaucratic set ups (see, e.g., Bredesen \& Friis, 2019). In 2020, the Bjarnason report-commissioned by the Nordic foreign ministers as a follow-up to the Stoltenberg report-recommended that the Nordic states should "build on and expand the Nordic brand," assume leadership on the international stage, and formulate Nordic re- sponses to three key policy challenges: climate change; hybrid and cyber threats; and threats to multilateralism and the rules-based international order (Bjarnason, 2020 , pp. 2-3). The report proposed developing common Nordic policies, approaches, or understandings in several areas and, where possible, the pooling of resources and the establishment of common structures. Here, it may be worthwhile noting that the Nordics have often had the ambition to join forces and speak with a common voice, as they share overarching priorities concerning, for example, multilateralism and development work. However, scholars have noted that Nordic cooperation, for example at the UN, has been less extensive than one might expect and has also become less apparent since the EU also started to develop similar ambitions for greater coordination (Laatikainen, 2003). One reason may be that when the Nordic states work together, they run the risk of appearing as moralistic, 'selfrighteous,' or 'smug,' as a Swedish foreign minister once observed (Wallström, 2018). Another is that the Nordic states themselves have called for the breaking up of permanent voting coalitions in the UN. Hence it might appear contradictory, even hypocritical if Nordic 'gangingup' became too apparent. Along with the stickiness of established national repertoires and the inclination to preserve individual niches, these factors could be said to hinder full activation of a Nordic foreign policy repertoire.

\section{Conclusion}

In the early Cold War years, the Nordic states' geopolitical location, war experiences, geographical proximity to and relationship with dominant powers, as well as their self-understanding as foreign policy actors, led them to pursue different paths in the formulation of foreign and security policies. The differences in choice gave rise to the idea of 'a Nordic balance' - the idea being that the Nordic states' foreign and security policy choices complemented one another and helped reduce great power tensions in the region as a whole (Brundtland, 1966). Following Tilly (1979), we have argued here that structural constraints, along with self-perceptions, resources, and established routines, are constitutive of the individual Nordic states' foreign policy repertoire: What these states can do, what they know how to do, and what others expect them to do in the international political arena (see also Tarrow, 1994). The concept of repertoires thus draws attention to the path-dependency of foreign policy in terms of expertise within a state's diplomatic corps, the networks it can mobilize internationally, its international reputation, and the organizational machinery (budgets, offices, practices) used to implement policy. We have argued that these individual repertoires are key to understanding the continued lack of a 'common order' among the Nordic states in the foreign policy domain. Despite oft-stated political ambitions to move in such a direction, and despite the narratives about Nordic 'likemindedness' and similarities in the organization and 
implementation of foreign policy, collaboration in this domain continues to be marked by talk rather than coordinated action, and case-by-case initiatives rather than formalized procedures. We noted at the outset that in foreign policy, shared socioeconomic and political traits do not increase the likelihood of cooperation. This can be put even more starkly: Such similarities can at times reduce the likelihood of cooperation and that we can talk of a 'narcissism of small differences.' Finland and Sweden's neutrality and freedom from alliances during the Cold War spawned foreign policy repertoires and identities that still work against full convergence with NATO members Denmark and Norway, despite changing power political dynamics. Similarly, the Nordic states' relationships with the EU is marked by distinguished models of integration as well as specific relational identities, which structure not only each state's relationship to the EU but also the Nordic states' relations with one another. A more organized, common Nordic approach within the EU is, therefore, less available as a course of action.

We see the Nordic states' foreign policies as being formulated and conducted in a structured environment where they depend on support and attention from more powerful states to advance their interests: Given their relative smallness in terms of economic size and political posture, an overarching foreign policy strategy has been to establish and maintain good relations with more powerful international players. This attention-seeking game is one where smaller states compete for access to and attention from significant other states to advance their national interests. Each Nordic state has over time developed a distinct repertoire that involves niche competencies and resources that are being used to signal distinctiveness vis-à-vis others. Seen from Copenhagen, Helsinki, Oslo, Reykjavik, or Stockholm, the safest bet in gaining access and attention in Washington, DC will often not be to foreground similarities with Nordic neighbours. It remains an open question whether such a 'narcissism of small differences' will continue to characterize future relations with an increasingly powerful China. The Nordics have, broadly speaking, similar interests in their relations with the emerging great power, organized around trade and investments. However, and as shown above, approaches to China have so far differed, not least with respect to the balancing between trade interests and the voicing of concern over human rights. Against this backdrop, we conclude that while Nordic governments and populations are generally positive to a further strengthening of Nordic foreign policy cooperation, there tends to be a decoupling between publicly stated ambitions, and action and resource allocation towards joint foreign policy initiatives beyond the Nordic region. As long as each Nordic state continues to treat Nordic cooperation as part of their individual foreign policy repertoire, rather than committing to developing a collective Nordic foreign policy repertoire, the overarching Nordic foreign policy coordination is likely to remain ad hoc and on a case-by-case basis.

\section{Acknowledgments}

The research was made possible by research grants from the Research Council of Norway, grant no. 250419 and 287131. We would like to thank the Academic Editors of Politics and Governance and three anonymous reviewers for constructive engagement with our article.

\section{Conflict of Interests}

The authors declare no conflict of interests.

\section{References}

Adler-Nissen, R. (2014). Opting out of the European Union: Diplomacy, sovereignty and European integration. Cambridge: Cambridge University Press.

Andersen, L. R. (2018). Det nødvendige og det mulige: Aktuelle spændinger i dansk udenrigspolitik [The neccessary and the possible: Current tensions in Danish foreign policy]. Internasjonal Politikk, 76(2), 316-330.

Andreasson, U., \& Stende, T. (2017). Et värdefullt samarbete: Den nordiska befolkningens syn på Norden [A valuable cooperation: The Nordic population's attitudes towards the Nordic region] (Analysis No. 03/2017). Copenhagen: Nordic Council of Ministers.

Bailes, A. J. K., Herolf, G., \& Sundelius, B. (Eds.). (2006). The Nordic countries and the European Security and Defence Policy. Oxford: Oxford University Press.

Bjarnason, B. (2020). Nordic foreign and security policy 2020: Climate change, hybrid \& cyber threats and challenges to the multilateral, rules-based world order. Reykjavik: Nordic Foreign and Security Policy.

Bredesen, M. G., \& Friis, K. (2019). Governance entrepreneurs as spoilers in nordic Defence cooperation. Journal of Regional Security, 14(2), 77-100.

Breitenbauch, H. (2017). Det store nordiske rum: Trump, Putin og geopolitikkens uafvendelighed [The large Nordic space: Trump, Putin and the inevitability of geopolitics]. Internasjonal Politikk, 75(1), 45-51.

Brundtland, A. O. (1966). The Nordic balance: Past and present. Cooperation and Conflict, 1(4), 30-63.

Butler, J. (1997). The psychic life of power: Theories in subjection. Stanford, CA: Stanford University Press.

Carlsnaes, W. (2013). Foreign policy. In W. Carlsnaes, T. Risse, \& B. A. Simmons (Eds.), Handbook of international relations (2nd ed., pp. 298-325). London: Sage.

Checkel, J. T. (2005). International institutions and socialization in Europe: Introduction and framework. International Organization, 59(4), 801-826.

Cooley, A., \& Nexon, D. (2020). Exit from hegemony: The unravelling of the American global order. Oxford: Oxford University Press.

Creutz, K. (2018). Finlands pragmatiska kurs i de globala omvälvningarnas svallvågor [Finland's pragmatic course in the global upheavals]. Internasjonal Politikk, 76(2), 331-342. 
Duvall, R. D., \& Chowdhury, A. (2011). Practices of theory. In E. Adler \& V. Pouliot (Eds.), International practices (pp. 335-354). Cambridge: Cambridge University Press.

Epstein, C., Lindemann, T., \& Sending, O. J. (2018). Frustrated sovereigns: The agency that makes the world go around. Review of International Studies, 44(5), 787-804.

Fägersten, B., Gunnarsson, P., Haugevik, K., Jokela, J., Sørensen, C., Thorhallsson, B., \& Wivel, A. (2018). Nordic responses to Brexit: Making the best of a difficult situation (Policy Brief). Oslo: Norwegian Institute of International Affairs.

Fägersten, B., \& Jerdén, B. (2018). Den moraliska stormakten $i$ en post-neutral era: Svensk utrikespolitik 2011-2018 [The moral superpower in a postneutral era: Swedish foreign policy 2011-2018]. Internasjonal Politikk, 76 (2), 343-354.

Finnemore, M. (1996). National interests in international society. Ithaca, NY: Cornell University Press.

Forsby, A. B. (Eds.). (2019). Nordic-China cooperation: Challenges and opportunities (NIAS Report No. 52). Copenhagen: Nordic Institute of Asian Studies.

Goddard, S., MacDonald, P., \& Nexon, D. (2019). Repertoires of statecraft: Instruments and logics of power politics. International Relations, 33(2), 304-321.

Hansen, F. S. (2018). Danske billeder af Rusland i 2010'erne [Danish images of Russia in the 2010s]. Nordisk Østforum, 32, 153-173.

Hansen, L., \& Wæver, O. (Eds.). (2002). European integration and national identity: The challenge of the Nordic states. Abingdon: Routledge.

Haugevik, K. (2017). Diplomacy through the back door: Norway and the bilateral route to EU decisionmaking. Global Affairs, 3(3), 277-291.

Haugevik, K., \& Sverdrup, U. (Eds.). (2019). Ten years on: Reassessing the Stoltenberg report on Nordic cooperation. Reykjavik: University of Iceland.

Holst, J. J. (1990). Foreword: Nordic security: Past mirrors and future faces. The Annals of the Academy of Political and Social Science, 512(1), 8-15.

Hopf, T. (2010). The logic of habit in international relations. European Journal of International Relations, 16(4), 539-561.

Hyde-Price, A. (2018). Epilogue: "Nordicness": Theory and practice. Global Affairs, 4(4/5), 435-443.

Ingebritsen, C. (1998). The Nordic states and European unity. Ithaca, NY: Cornell University Press.

Ingebritsen, C. (2002). Norm entrepreneurs: Scandinavia's role in world politics. Cooperation and Conflict, 37(1), 11-23.

Iso-Markku, T., Innola, E., \& Tiilikainen, T. (2018). A stronger north? Nordic cooperation in foreign and security policy in a new security environment. Helsinki: Prime Minister's Office.

Jakobsen, P. V. (2017). The United Nations and the Nordic four: Cautious sceptics, committed believers, cost-benefit calculators. In P. Nedergaard \& A. Wivel
(Eds.), The Routledge handbook of Scandinavian politics (pp. 289-293). Abingdon: Routledge.

Jakobsen, P. V., Ringsmose, J., \& Saxi, H. L. (2018). Prestige-seeking small states: Danish and Norwegian military contributions to US-led operations. European Journal of International Security, 3(3) 256-277.

Kragh, M. (2018). Sveriges relationer med Ryssland: kontinuitet och förändring historiskt och idag [Sweden's relations with Russia: Continuity and change, historically and today]. Nordisk Østforum, 32, 54-74.

Laatikainen, K. V. (2003). Norden's eclipse: The impact of the European Union's Common Foreign and Security Policy on the Nordic group in the United Nations. Cooperation and Conflict, 38(4), 409-441.

Lake, D. A. (2009). Hierarchy in international relations. Ithaca, NY: Cornell University Press.

Leruth, B., Gänzle, S., \& Trondal, J. (2018). Differentiated integration and disintegration in the EU after Brexit: Risks versus opportunities. Journal of Common Market Studies, 57(6), 1383-1394.

Lindemann, T., \& Ringmar, E. (2015). International politics of recognition. Abingdon: Routledge.

Mitzen, J. (2006). Ontological security in world politics: State identity and the security dilemma. European Journal of International Relations, 12(3), 341-70.

Mouritzen, H. (1995). The Nordic model as a foreign policy instrument: Its rise and fall. Journal of Peace Research, 31(1), 9-21.

Neumann, I. B., \& Sending, O. J. (2020). Performing statehood through crises: Citizens, strangers, territory. Journal of Global Security Studies. https://doi. org/10.1093/jogss/ogz073

Niinistö, S. (2016). Remarks at the Nordic leaders' summit arrival ceremony. Washington, DC: White House.

Nordic Council. (2017). International strategy of the Nordic Council 2018-2022. Copenhagen: Nordic Council.

Peters, B. G., Pierre, J., \& King, D. S. (2005). The politics of path dependency: Political conflict in historical institutionalism. The Journal of Politics, 67(4), 1275-1300.

Pouliot, V. (2008). The logic of practicality: A theory of practice of security communities. International Organization, 62(2), 257-288.

Pouliot, V. (2020). Historical institutionalism meets practice theory: Renewing the selection process of the United Nations Secretary-General. International Organization. https://doi.org/10.1017/ S002081832000020X

Rieker, P. (2006). Europeanization of national security identity: The EU and the changing security identities of the Nordic states. Abingdon: Routledge.

Røren, P. (2019). Status seeking in the friendly Nordic neighborhood. Cooperation and Conflict, 54(4), 562-579.

Rowe, E. W. (2020). Analyzing frenemies: An Arctic repertoire of cooperation and rivalry. Political Geography, 76, 1-10. 
Rowe, L. (2018). Fornuft og følelser: Norge og Russland etter Krim [Sense and sensibility: Norway and Russia after Crimea]. Nordisk Østforum, 32, 1-20.

Rumelili, B., \& Towns, A. (in press). International rankings as normative goods: Hegemony and the quest for social status. In M. Andersen, A. Cooley, \& D. Nexon (Eds.), Undermining American hegemony: The logic of goods substitution in world politics. Cambridge: Cambridge University Press.

Smith, H. (2018). EU-medlem och Rysslands granne: En analys av Finlands strategiska kultur [EU member and Russia's neighbour: An analysis of Finland's strategic culture]. Nordisk Østforum, 32, 87-103.

Søreide, I. E., Wammen, N., Haglund, C., Sveinsson, G. B., \& Hultqvist, P. (2015, April 9). Russisk propaganda bidrar til å så splid [Russian propaganda contributes to sowing discord]. Aftenposten. Retrieved from https://www.aftenposten.no/meninger/kronikk/ i/wnao/fem-nordiske-ministre-i-felles-kronikkrussisk-propaganda-bidrar-til

Stie, A. E., \& Trondal, J. (2020). Introducing the study of Nordic cooperation. Politics and Governance, 8(4), 1-10.

Stoltenberg, T. (2009). Nordic cooperation on foreign and security policy: Proposals presented to the extraordinary meeting of Nordic foreign ministers in Oslo on 9 February 2009. Oslo: Nordic Cooperation on Foreign and Security Policy.

Støre, J. G. (2009). Letter to Alexander Stubb, 17 September. Oslo: Norwegian Government. Retrieved from https://www.regjeringen.no/globalassets/upload/ ud/vedlegg/fn/g20_brev090917.pdf

Strang, J. (2016). Introduction: The Nordic model of transnational cooperation? In J. Strang (Ed.), Nordic cooperation: A European region in transition (pp. 1-26). Abingdon: Routledge.

Sverdrup-Thygeson, B., \& Hellström, J. (2016). Norden og Kina: En ukoordinert kvintett? [The Nordic states and China: An uncoordinated quintet?]. Internasjonal Politikk, 74(3), 1-7.

Sverdrup-Thygeson, B., Lindgren, W. Y., \& Lanteigne, M. (2017). China and Nordic diplomacy. Abingdon: Routledge.

Tarrow, S. (1994). Power in movement: Social movements and contentious politics. Cambridge: Cambridge University Press.

Thorhallsson, B. (2018). A small state in world politics: Iceland's search for shelter. Icelandic Review of Politics \& Administration, 14(1), 61-82.

Tilly, C. (1979). Repertoires of contention in America and Britain, 1750-1830. In M. N. Zald \& J. D. McCarthy (Eds.), The dynamics of social movements (pp. 126-155). Cambridge: Winthrop Publishers.

Tilly, C. (2006). Regimes and repertoires. Chicago, IL: University of Chicago Press.

Wæver, O. (1992). Nordic nostalgia: Northern Europe after the Cold War. International Affairs, 68(1), 77-102.

Wallström, M. (2018). Speech at the Nordic Council, Oslo, 31 October. Oslo: Nordic Council.

\section{About the Authors}

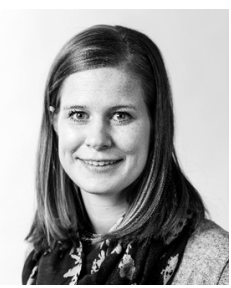

Kristin Haugevik is Senior Research Fellow at the Norwegian Institute of International Affairs (NUPI) and Head of the Institute's research group Global Order and Diplomacy. Her research revolves around inter-state cooperation, friendship and diplomacy, with a geographical focus on the European and transatlantic region.

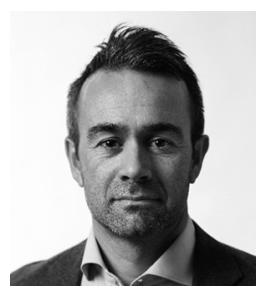

Ole Jacob Sending is Research Professor and Director of Research at the Norwegian Institute of International Affairs (NUPI). His research focuses on the role and functioning of international organizations and on the evolution of statehood under conditions of globalization. 